1990

\title{
Lawyers against the Emergency
}

Stephen J. Ellmann

New York Law School, stephen.ellmann@nyls.edu

Follow this and additional works at: http://digitalcommons.nyls.edu/fac_articles_chapters

\section{Recommended Citation}

6 S. Afr. J. on Hum. Rts. 228 (1990)

This Article is brought to you for free and open access by the Faculty Scholarship at DigitalCommons@NYLS. It has been accepted for inclusion in Articles \& Chapters by an authorized administrator of DigitalCommons@NYLS. 


\title{
LAWYERS AGAINST THE EMERGENCY*
}

\author{
STEPHEN ELLMANN**
}

For the past four years many South African lawyers have devoted great effort and ingenuity to the practice of emergency law on behalf of the victims of the emergency. From the start, this work has had an ironic quality. Confronting a government armed with legal powers so vast as to call into question the legitimacy of the law itself, attorneys and advocates have nonetheless sought to fashion legal limits on the state's authority. The effort has been difficult, and those who have made the effort, courageous. Yet it might be argued that this legal struggle has been in vain, and that, indeed lawyers who have practised in this field have misdirected their energies. My purpose in this article is to demonstrate that this argument is mistaken. I will try to explicate a judgment that many South African lawyers have undoubtedly already made - namely that, despite the limited legal success which those who represent the victims of emergency law have had, their efforts have been fruitful as well as noble. ${ }^{1}$

The case for the practice of emergency law against the state would be much easier to make if the courts had proved more receptive to lawyers' efforts to restrain the government's power. Many commentators in this journal have pointed to the promising decisions of some provincial courts early in the emergency, but no one now needs to be reminded that under the leadership of Rabie ACJ the Appellate Division largely dashed the hopes that those judgments had raised. In the aftermath of Staatspresi-

* On 8 June 1990 the nation-wide state of emergency that had been in force from 12 June 1986 came to an end. This article, which was written while the emergency was in force, is still, however, of relevance. First, because it raises issues that go beyond emergency law. Secondly because the emergency continues in Natal (Eds).

** BA JD (Harvard), Associate Professor of Law, Columbia Law School. This article owes a great deal to what I have learned from conversations with many South Africans. I am also grateful to Robert Andur, Mark Barenberg, George Bizos, Greg Bloche, Geoff Budlender, Edwin Cameron, Arthur Chaskalson, Stephen Cohen, Lori Damrosch, Jerry Lynch, Eben Moglen, Henry Monaghan, Nancy Rosenbloom, and Peter Strauss, among others, for their helpful comments on earlier versions of this piece. Nadine Havenga's translations of Afrikaans legal materials have been essential to my study of South African law. Columbia Law School and the Parker School of Foreign and Comparative Law have provided financial support. Responsibility for the arguments and conclusions expressed here, however, is solely my own.

1 This article is a modified part of a larger project to be published by Oxford University Press, in which I look closely at critical Appellate Division decisions dealing with the state of emergency before turning to the present discussion of the role of lawyers. 
dent $v$ United Democratic Front ${ }^{2}$ perhaps the most disturbing of these decisions, Etienne Mureinik wrote that ' $[\mathrm{m}]$ any of our finest lawyers are confessing. . .to despondency', though he also maintained that 'despair . . .would be premature'. ${ }^{3}$

Later in this article I will look briefly at the principles of emergency law that the Rabie Court left as its legacy. We do not need to perform this examination yet, however, to recognize that South African emergency law could be worse. We can imagine, or if we wish we can simply read about, legal systems in which many people are completely - not just substantially - without hope. During a five-year period of Argentina's most recent military rule, for example, only a single habeas corpus petition succeeded out of thousands filed, and that petition dealt with the case of Jacobo Timerman, by then a focus of sharp international concern. ${ }^{4}$ Moreover, in the cases of those who had not officially been arrested but instead had 'disappeared', as Alejandro Garro wrote in 1983 , '[n]ot even one out of the many thousands of petitions for habeas corpus has succeeded in recovering a missing person alive'. ${ }^{5}$ If the efforts of South African lawyers did no more than to ensure that those held in detention without trial were periodically heard from in court, the result would be better than a system in which the same people were never heard from at all. ${ }^{6}$

21988 (4) SA 830 (A).

3 E Mureinik 'Pursuing Principle: The Appellate Division and Review Under the State of Emergency' (1989) 5 SAJHR 60 at 72.

4 A M Garro 'The Role of the Argentine Judiciary in Controlling Governmental Action Under a State of Siege' (1983) 4 Human Righis $L J 311$ at 332.

5 At 335 .

6 One argument that could be made against this proposition would be the claim that the very fact that some constraints apply to the state's lawful powers encourages those who wish to shed those constraints to resort to bluntly illegal means. In a nation which embraces draconian legal powers in an effort to avoid the limits of its normal law, those dissatisfied with the efficacy even of emergency powers may feel that still more drastic steps are called for.

Whether this argument is correct is a complicated empirical question. Constraining the state may result in an overall increase in human rights protection, at the same time that it encourages limited vigilante action by a few who resist these constraints. Holding the state to higher standards may result in no increase in unlawful conduct at all, if efforts are made simultaneously to challenge those who might choose to act unlawfully. Indeed, loose constraints on official action may coexist with, or even reinforce, thoroughly lawless behaviour beyond the fringes of the state's structures.

Whatever the cause, in South Africa today there is chilling evidence that repression of anti-apartheid struggles is not confined to the use of elaborate legal weapons available to the government, but extends as well to extra-legal methods such as bombings, murders and vigilante violence. There is also reason for suspicion that the perpetrators of these crimes have links, of greater or lesser intimacy, with state structures.

Condemning and if possible stopping this extra-legal violence is obviously very important. Even if the presence of some limits on the state's lawful authority contributed to the rise of this illegal violence, however, abandoning those limits would be a poor solution to the problem. Such an abandonment might well give further encouragement to those behind this violence. Moreover, a country should have neither vigilante violence nor unlawful police action; accepting one to avoid the other is not a victory. It might be unbearable morally to submit to the latter in order to avoid the former, even if such a strategy seemed likely to work. 
To say that South African emergency law could be worse, however, is not necessarily to say that the difference that it makes is so important that lawyers who seek to challenge apartheid should put their efforts into this field. Nor, after all, is it self-evident that people who are opposed to apartheid should put their efforts into legal challenges to the features of this system, in the field of emergency law or elsewhere. Although the courts have been more receptive to lawyers' efforts outside the field of emergency law, it could be argued that even in other fields the ultimate costs of relying on legal strategies outweigh the gains these strategies may sometimes bring.

Thus the question of the value of practising emergency law is a subpart of the question of the value of practising law in South Africa at all. We might first ask, therefore, whether people opposed to apartheid should undertake the practice of law of any sort in South Africa. Then, if we conclude that at least some forms of legal practice do make sense for opponents of apartheid, we could ask whether the choice to practice in the field of emergency law rather than in other areas (labour law, for example) is also a justifiable one.

It seems to me, however, that the arguments for and against any practice of law in South Africa are broadly similar to those which may be made with respect to emergency law in particular. In what follows, accordingly, I will first try to assess the arguments bearing on the practice of emergency law, on the assumption that a focus on this field will exemplify the questions bearing on any anti-apartheid lawyer's decision to practice. I will suggest that emergency law is worth practising, and that, for roughly the same reasons, many other fields of South African law are as well. Having reached this broad conclusion, I will look briefly at the question of whether emergency law is so worthwhile a field that anti-apartheid lawyers may properly decide to give this field a priority over other fruitful areas of practice.

Is the practice of emergency law worth the effort? It may seem presumptuous for anyone, and especially for an American, to offer an answer to such a question. The question, after all; ultimately calls for an assessment of the present state and future prospects of South African society; for a gauging of the strength of the various forces for and against change in that land; for an understanding of the relation between lawyers' efforts, in and out of court, and other challenges to apartheid, a relation that may prove complementary or conflicting; for an understanding of the alternatives open to those who might undertake emergency law cases; and for a grasp of what makes difficult and even frustrating work 'worth it' to an individual. Each of these subsidiary questions is immensely difficult and some may simply be unanswerable.

Yet the broad question does need to be asked, and answered, South African lawyers opposed to apartheid, and those of similar conviction who might become lawyers, have no alternative but to address it. 
Americans concerned about South Africa, I think, are equally without the option of ignoring this issue, since we must decide whether to support these efforts, tangibly or morally. If such work is fruitless or even counterproductive, then we should not aid it; if it is valuable, perhaps we should aid it more. As individuals, as citizens of South Africa or of the United States, and in particular as lawyers we must offer the best answer we can, aware as we will be that our answer cannot resolve all the difficulties that the question presents. ${ }^{7}$

I will attempt to answer this question with two arguments. I will contend, first, that lawyers cannot simply rely on the fact that the victims of emergency powers want representation as a sufficient justification for working on these victims' behalf. Instead, lawyers themselves have an inescapable responsibility for assessing the value of their work. But I will maintain, second, that the endorsement reflected in clients' requests for representation is a well-founded one. Emergency law work, I will try to show, is of value, both for the benefits it can win for individual clients and for its broader political impact on South Africa. Let us turn to these matters now.

\section{LAWYERS' MORAL RESPONSIBILITY FOR THEIR WORK}

Perhaps we should say that so long as people opposed to apartheid choose to practise law, they should represent the victims of South African security powers if the victims want representation. It seems quite clear that the victims' position is almost always that they wish to have legal counsel. Exceptions to this generalization exist, but they are few and far between. Even when those accused of crimes refuse to participate in their trials as an expression of their rejection of the courts' authority to punish them, they may choose to continue to receive legal advice. ${ }^{8}$ If the victims' wishes are dispositive, then clearly lawyers should pursue even such limited victories as this frustrating field of law may permit.

But should lawyers defer to their would-be clients' judgment? I do not

7 Our answer to this broad question may also help us to address other issues, although I doubt that it will dictate their solution. If American companies doing business in South Africa provide donations that support anti-apartheid legal work, should calls for divestment be tempered? If South African lawyers doing such work can find intellectual stimulation and emotional support in American university communities, should such lawyers be welcomed to American law schools as graduate students or visiting professors, or should such contacts be proscribed as part of a cultural boycott of South Africa? Should anti-apartheid South African lawyers be welcome in international fora while anti-apartheid South African athletes are banned from the Olympic Games? I will not address these subordinate questions here.

8 In a recent trial, $S v$ Masina TPD 25 April 1989 Case No cc400/88, unreported, members of Umkhonto we Sizwe took the position that 'civilian courts' had no authority to try them and 'refused to plead and participate in the court proceedings'. Nonetheless they were represented by a Johannesburg law firm. V Gunene 'No Remorse as Delmas Trio Convicted' Weekly Mail 3 March 1989 at 4. Ultimately evidence in mitigation of sentence in this case was led 'by lawyers instructed by the families of the accused men'. V Gunene 'Judge Outvoted - So Three Will Hang' Weekly Mail 28 April 1989 at 1. 
mean to ask here whether lawyers have an obligation under South African rules of professional ethics to accept whoever comes to them as a client and is able to pay their fee. South African advocates do have such an obligation, though attorneys in general do not. ${ }^{9}$ The cases that come to a lawyer, however, surely tend to be those in which the lawyer is expert and interested. This relationship may be especially direct when the cases are as highly charged as emergency matters can be. Even for those lawyers subject to the taxi-rank principle, therefore, the question of whether to defer to potential emergency clients' desire for representation is a live one - for these lawyers can so structure their practices and careers as to discourage or instead encourage such cases to arrive in the queue. Hence it is important for advocates and attorneys alike to consider whether the value of their efforts in the emergency law field, or in the practice of law in general, is established by the fact that clients desire and value those efforts.

To raise this question is not to suggest that clients' wishes are unimportant to lawyers' obligations. Nonetheless, what clients want is not necessarily what lawyers must, or even may, do. Let us consider three respects in which clients' wishes are not altogether dispositive. First, clients may reasonably desire that their lawyers violate the rules of professional ethics so as to help the clients win their cases. Clients who deny the moral legitimacy of the state may find the notion that their cases should be circumscribed by the same state's ethical prescriptions particularly implausible. Plainly, however, lawyers opposed to apartheid and ready to answer clients' calls for representation can be entirely unwilling to accede to requests for unethical conduct. Such lawyers have decided, whether for tactical or moral reasons, to offer their clients only vigorous representation within the law, and to limit their offer of aid in this way despite the clients' possible desire for less scrupulous assistance. 10

For any lawyer who adopts this position, clients' wishes are obviously not wholly determinative. Ultimately such lawyers would need to ask whether their decision to give representation should be governed by clients' wishes when their decision as to the type of representation to give is not entirely left to client direction. I do not mean to explore here what arguments would explain this seeming disparity in the weight accorded to

9 See, 'Uniform Rules of Professional Ethics of the General Council of the Bar as Adopted by the Johannesburg Bar', Rule 2.1, in Rules of Professional Ethics of the Johannesburg Bar (May 1986); E A L Lewis Legal Ethics: A Guide to Professional Conduct for South African Attorneys (1982) 75.

10 Analysis of these reasons is a complex question in itself, and one which this article will not explore. In discussing the value of legal practice in this article, I mean to argue for the value of a legal practice that adheres to the normally applicable rules of professional ethics. If the argument set out here is correct then it would tend to show that the practice of emergency law and of other aspects of anti-apartheid law in South Africa is a worthwhile enterprise even if on occasion a case that might be won is lost because of the practitioners' adherence to principles of legal ethics. 
client preference, or to suggest that it is inexplicable. My object is only to clarify the role that clients' wishes are being assigned.

Second, client wishes - at least conscious, articulated client wishes are not a necessary predicate for lawyers engaging in some aspects of the practice of law with actual or potential clients. I think that this point holds true even for lawyers who shape their practice in a quite traditional manner. Imagine a man in detention who tells his lawyer that he is not being properly fed. This is an important matter, and the client obviously wants something done about it. But perhaps the client assumes that nothing can be done about the sheer fact of his detention, and so makes no request that the lawyer try to free him from imprisonment. A lawyer who learns that the client has a valid basis for obtaining his freedom would be remiss, however, if she did not inform the client of this fact and ask whether the client wanted her to press this claim. ${ }^{11}$ Providing the client with this information is part of the practice of law, but in this instance it is not elicited by an express request from the client.

It is fair to respond that the lawyer is acting in light of an understanding, or assumption, about the client's unexpressed desires, and a reasonable assumption at that. On this account, the lawyer is not really deviating from her client's wishes. Once we accept the legitimacy of acting in accordance with unexpressed, inferred wishes, however, we must also consider the possibility that the wishes that clients do express are not those which they would endorse if they were properly counselled and fully informed.

For example, lawyers consulting with clients in detention might reasonably assume that many or most of their clients would not want to engage in court action if that action were likely to provide more benefit to the government of South Africa than to the clients themselves. On the basis of this assumption, such lawyers would not regard their clients' initial expression of a desire to go to court as dispositive. If the lawyers believed that emergency litigation was ultimately misguided, they could legitimately argue that it was proper, or even obligatory, for them to convey their view of the value of emergency litigation to their clients, so that the clients could decide in light of this advice whether to proceed with litigation or not. ${ }^{12}$ A lawyer of this mind could firmly adhere to the principle that the client's ultimate, informed choice is controlling - yet just as firmly assert the propriety of urging the client not to undertake litigation that the client had initially stated a desire to undertake. ${ }^{13}$

11 In this article I sometimes use masculine pronouns to refer to clients and feminine pronouns to refer to lawyers. All such pronouns should be understood to encompass people of both sexes.

12 I have argued in an American context that this sort of counselling, if carried out in a nonmanipulative manner, is part of a practice of law that truly serves client autonomy. See S Ellman 'Lawyers and Clients' (1987) 34 UCLA LR 717 at 774-8.

13 Even a lawyer dealing with a client who initially expressed a desire precisely to sacrifice the greater good for his own personal needs would not, on this logic, be constrained to accept the client's 
Third, in at least one context clients' wishes - even if these wishes are entirely lawful, and even if they are a necessary predicate for lawyers' action - cannot be a sufficient predicate for this work. If there are more potential clients than lawyers have time to represent, then lawyers have no alternative but to choose which cases they will take. This situation must exist, at least potentially, for any lawyer contemplating legal work on behalf of the victims of apartheid in South Africa. Lawyers may have to choose between deserving cases that arrive simultaneously in their office. Even more clearly, they must choose over time the sorts of deserving cases that they will take.

Moreover, anti-apartheid lawyers obviously also have the option to decide to shape a nonpolitical practice (because, for example, they believe no good will come from a politically-guided practice, and look on the law as simply a means of earning a living), and there are no doubt potential nonpolitical clients who would desire their services as well. In addition, anti-apartheid lawyers are not forced to be lawyers; they might decide to forego the practice of law in favour of other forms of work such as community organizing, for which there surely is also considerable demand. The magnitude of the need, and the variety of possible professional responses to it, mean that lawyers in South Africa, and their supporters abroad, cannot escape the necessity of choice.

\section{The Value of Emergency Law Work}

Lawyers might make the choice to reject their would-be clients' requests for assistance if they believed that the clients were being wrong-headed. They might reach this judgment on either of two grounds. First, lawyers might conclude that their clients were mistaken in believing that their particular cases would fare better with legal assistance than without. Second, lawyers might maintain that even though their presence would aid the particular individuals whom they represented, the ultimate effect of their efforts would be to undercut the broader struggle against apartheid. I will argue that both of these positions are mistaken. Since they raise somewhat different considerations, however, I will look at them separately.

\section{(a) Do emergency lawyers help their clients?}

Lawyers would have good reason to grow despairing about the practice of emergency law if they were unable to help their clients through this practice. Moreover, it is possible to imagine situations in which lawyers' 
intervention might fail to help, or succeed in harming, their clients' interests. A lawyer who believes, for instance, that litigation about allegations of torture will not persuade the courts to grant relief, but may succeed in further antagonizing abusive law enforcement officers, might well consider the entire enterprise misguided. Despite the well-known legal defeats emergency lawyers have suffered in the Appellate Division, however, I believe the efforts of emergency lawyers overall are far from fruitless. ${ }^{14}$

These efforts remain valuable in part because some of what lawyers do for their clients can be accomplished without explicit courtroom victories either in the provincial divisions or on appeal. We can see this even in the field of emergency detentions, one of the areas in which the state's powers are at their zenith. As is well known, the Appellate Division decided in Omar, perhaps the worst of its detention decisions, that the state had the power to deny detainees access to their counsel..$^{15}$ Yet many, perhaps almost all, detainees do succeed, often with permission, in obtaining access to counsel and others in the outside world. This contact is psychologically important in and of itself.

Moreover, such contacts can lead to litigation. Despite the state's power under Omar to interfere with detainees' access to lawyers and so to the courts, cases are brought (and presumably others that are never brought are threatened) on behalf of detainees. Some of these cases do result in at least partial victories in court - occasionally even in the Appellate Division. ${ }^{16}$ Perhaps others lead to useful settlements out of court. Still others, by bringing judicial attention or even newspaper publicity to bear, may help constrain officials who never are subjected to an actual judgment or settlement binding them. All of them help ensure that detainees do not disappear.

I think that even though the cases in which courts will grant relief will be few, and even though the broad contours of the emergency system will unquestionably be left intact, the potential for a constant legal war of attrition is a significant check on the worst potentials under the states of emergency. ${ }^{17}$ In such a context, valuable results may be achieved even though the broad brush with which the Appellate Division paints has been

14 I do not mean to suggest that there are no fruitless cases in the emergency law field. Rather, my point is that there are many fruitful ones.

15 Omar $v$ Minister of Law and Order 1987 (3) SA 859 (A).

16 See Nkwentsha $v$ Minister of Law and Order 1988 (3) SA 99 (A); Apeleni and Lamani v Minister of Law and Order 1989 (1) SA 195 (A).

17 An illustration from outside South Africa of the impact that determined lawyers may have on the working of a legal system is the continuing effort to combat capital punishment in the state and federal courts of the United States. As of August 1989, this effort has held the number of executions to less than 120 over the period of more than 13 years that has passed since the Supreme Court ruled in 1976 that the death penalty was not per se unconstitutional. This success has been achieved despite the broad popularity of capital punishment in the United States today and despite the presence of thousands of convicted men and women on death rows around the nation. 
increasingly grimly hued. I suspect, too, that even though the Appellate Division has rejected many of the legal initiatives of lower courts in emergency cases, the lower court decisions have somewhat tempered some of the worst steps the government sought to take - a tempering that makes the Appellate Division's lack of vigilance less immediately damaging.

When we measure what is to be gained in these cases, moreover, we need to remember the possibility of change in the courts' performance. Obviously change can be for better and for worse, but there are at least three reasons for a modest optimism about future trends in the Appellate Division.

The first is that Acting Chief Justice Rabie has at long last been replaced by Chief Justice Corbett, a judge thought to be of less 'executive-minded' views. While we should be careful not to exaggerate the power of a single judge, South Africa's Chief Justice appears to wield very significant authority, if not sole control, over the selection of the judges who will hear cases. ${ }^{18}$ Corbett $\mathrm{CJ}$ can make a difference to future judgments merely by ensuring that the selection of courts is more representative of the Appellate Division as a whole than those of the recent past have been. ${ }^{19} \mathrm{He}$ may also, of course, enjoy intellectual influence on his colleagues on the bench. The Appellate Division's recent decision to overturn an emergency restriction order as so 'manifestly extravagant' that it was 'legally impeachable in its entirety' offers some confirmation of the hopes for the Corbett Court. ${ }^{20}$

A second reason is that despite the decisions of the Rabie Court South African law continues to provide the theoretical foundation for decisions protecting human rights. It is true that Rabie's service as Acting Chief Justice enabled the government to secure additional years in which the Appellate Division was headed by a justice to its liking. It may also be the case that Rabie sought to bind future judges of the Appellate Division as firmly as possible with the ties of stare decisis. Haysom and Plasket have argued in these pages that '[i]t is difficult to imagine how even a reconstituted Appellate Division could rescue our system of administrative law from the treatment it has received at the hands of the Rabie Court

18 This power appears to be more de facto than de jure. Section 12 of the Supreme Court Act 59 of 1959 explicitly gives the Chief Justice certain powers to determine the number of judges who will hear a case, but does not assign to the Chief Justice or to anyone else the power to select the judges.

19 For an analysis of the composition of the Appellate Division panels that heard security law cases from 1987 to 1989, see N Haysom and C Plasket 'The War Against Law: Judicial Activism and the Appellate Division' (1988) 4 SAJHR 303 at 309-10. Haysom and Plasket comment that 'Rabie ACJ must, we assume, bear some responsibility for the composition of the courts which hear security related matters' at 310 .

20 For a brief description of this case, Visagie $v$ State President, see Human Rights Commission Human Rights Update: April - June 1989 at 1 (July 1989), G Davis 'Judge Hands Down a Legal 'Crumb' to SA's Restricted 900' Weekly Mail 30 June 1989 at 2. 
- unless such a court were to be as creative in the face of recent precedent as the Rabie Court has been in the face of older precedent'. ${ }^{21}$

There is much to be said for just such judicial creativity in favorem libertatis in South Africa today. In many respects, moreover, the more benign doctrines of South African law, in Mureinik's words, 'have a great deal of resilience left in them yet' ${ }^{22}$ By and large the South African courts remain open, and access to them has been protected in such decisions as Nkwentsha and Apeleni. Most legally cognizable claims - though after Staatspresident v United Democratic Front not all - may still be heard.

Even decisions that have seriously undercut human rights have often done so more by manipulation than by transformation of existing doctrine. Dempsey, for example, does not abrogate the 'apply the mind' doctrine applicable to official action, though it weakens the force of this requirement significantly. ${ }^{23}$ Omar accepts various standard principles of the review of subordinate legislation, though it applies to them halfheartedly at best. Staatspresident $v$ United Democratic Front's validation of statutory ouster of jurisdiction over a vagueness claim is perhaps the sharpest deviation from prior trends, but doctrinally there is less even to this case than meets the eye. The arguments that Rabie ACJ and Hefer JA offer to support this ouster are so logically unsatisfactory that it can still be argued that no other challenges should be subject to ouster. In fact, both these judgments suggest other grounds for review that would not be ousted. Meanwhile, they remind readers that vague regulations remain unenforceable even if they cannot be declared invalid. 24

It is worth asking why the Rabie court did not make sharper revisions in the doctrines which it addressed. Perhaps the court simply did not need to do more than it did in order to decide cases for the government - and would and could have done more if the occasion had arisen. Perhaps the court also found the sheer weight of doctrine and precedent too great to alter quickly. The density of the law, on this account, gives it some durability. I suspect that there is another reason as well. This reason is that the court, even under Rabie, may have been reluctant to modify existing doctrine. Rabie, after all, was the author of Hurley ${ }^{25}$ and of Nkondo \& Gumede ${ }^{26}$ as well as of Omar and Staatspresident v United Democratic Front. At his best, Rabie was never a human rights advocate, but it seems possible that he and some of his colleagues saw themselves

21 Haysom and Plasket op cit note 19 at 305.

22 Mureinik op cit note 3 at 72.

23 Minister of Law and Order v Dempsey 1988 (3) SA 19 (A).

24 The observations concerning the case law here reflect the results of the analysis of these cases in the larger project of which this article is a part.

25 Minister of Law and Order v Hurley 1986 (3) SA 568 (A).

26 Nkondo \& Gumede v Minister of Law and Order 1986 (2) SA 756 (A). 
as restricting South Africans' legal rights only because the protection of the security system seemed to demand such change. Dismayed themselves by the necessity they perceived, these judges may have been less eager, perhaps even less able, to formulate the doctrinal basis for sharper shifts in the law.

That South African law may have been hard to change, and that judges deeply concerned with state security may not have relished the process of changing it, are reasons to hope that the fabric of the law will not be easy to tear even if the leadership of the court shifts again. In any event, for now the underlying principles have proved to have some durability. Future panels of the Appellate Division and of the provincial divisions still have significant discretion to vindicate human rights claims.

The third reason for optimism is that of the present political climate of the country as a whole. To say that the courts are affected by the political climate does not require any 'conspiracy theory' of the appointment and behaviour of South African judges. It is in fact quite startling to a foreign observer to see how many firm opponents of government policies have been appointed to the Supreme Court bench by the National Party government. Their presence and their impact suggest that here, too, the traditions of the legal system are remarkably resilient. The willingness of some less notably liberal judges to render decisions against the state is further evidence of the same point. ${ }^{27}$

Still judges are appointed by the government, and it is safe to assume that politics affect the appointment process. Some members of the bar may be unwilling to be appointed by a government that they abhor; the government may also be reluctant to appoint those lawyers of whom it deeply disapproves; and on occasion the government has appeared to manipulate the appointment process so as to give special advancement to individuals whom it favoured. In these and probably other ways, politics can directly affect the composition of the bench. Even where none of these factors operates, all members of the judiciary come from a privileged, often extremely privileged, sector of the South African society. This background in turn must influence the views of those who come to sit on the bench.

It is reasonable to expect that judges who perceive that those with whom they share beliefs or backgrounds are revising their judgments about security issues will not be wholly indifferent to this development. As I write in October, 1989, the government appears to be eager to demonstrate a receptivity to substantive change. Perhaps more important, the government has been opening up the channels of nonviolent political protest, and even speaks of lifting the state of emergency at least in part (though the number of emergency detainees has also been rising

27 The judgment of Rumpff $\mathrm{CJ}$ in Komani NO v Bantu Affairs Administration Board, Peninsula Area 1980 (4) SA 448 (A) is a particularly striking example. 
again). If the government truly embraces this course, we can expect judicial antennae to pick up the new direction. The government itself may make less aggressive use of emergency powers even if it retains the state of emergency. As a result, the Appellate Division may experience fewer occasions when it is urged to render executive-minded decisions, and may view such urging as it does receive with greater scepticism than did the Rabie court.

The upshot of this analysis is that clients' apparent belief that their individual interests will be served by having legal representation is correct. Their fates will be less grim if they have the aid of lawyers. And this effect will not be confined to the particular clients alone, for the protections that lawyers establish in any one case may shield other South Africans thereafter. Nonetheless it is possible to argue that these gains are outweighed politically by losses generated through the very process of pursuing relief within the existing legal structures. Let us now consider this political attack on the value of lawyers' work.

\section{(b) Do emergency lawyers undercut the struggle against apartheid?}

It can be argued that the best way to undercut apartheid is to reject it at every turn. For those who encounter the system of apartheid through South Africa's courts, the correct response would be to refuse to participate in the system's legal forms. Opponents of apartheid would seek to manifest the illegitimate character of the power that oppressed them by their refusal to participate.

A broad principle of non-participation is, in fact, the theory that guides much of black political life in South Africa today. 28 When Africans choose not to vote in segregated municipal elections - the only occasions on which South Africa accords them a right to vote outside their 'homelands' - they are seeking to undermine a structure of apartheid, rather than risk lending it legitimacy by their very participation. When other South Africans boycott Parliamentary elections, they are doing the same thing. The price of such boycotts is that a modicum of power falls into the hands of those blacks who for ideological or personal reasons are prepared to play the game, but that is a price that other blacks have been prepared to pay. In a similar vein, it could be argued that blacks and whites would be wise to turn away from the use of the law and of litigation altogether, even at the risk of personal suffering as the immediate result, for the sake of longer-term objectives.

The practice of those subjected to emergency powers appears to reflect their refusal to take this step. Perhaps, however, a sympathetic lawyer could conclude that this refusal is a mistake. Should a sympathetic lawyer 
substitute her judgment for that of the would-be clients, by refusing to take their cases? There would be two reasons not to adopt such a stance. The first would be a hesitation on the part of the lawyer to adopt the role of political activist and decision-maker; the second would be a judgment that the decisions to seek legal representation that clients have made are justified on political as well as individual grounds. I will argue that anti-apartheid lawyers do not have to be activists, but that even so they cannot avoid making some political choices. I will also suggest that lawyers' work should, on balance, be politically valuable rather than damaging.

Should anti-apartheid lawyers be political activists first and foremost? A lawyer who has chosen to focus part or all of her professional life on attempting to limit the depredations of apartheid is not a person who has excluded political and moral judgments from her field of responsibility. Perhaps such lawyers should take their principles one step further, and assert that it is their responsibility, rather than anyone else's, to decide which cases are so politically and morally productive that the lawyers should undertake them. Such lawyers might see themselves, and present themselves to the world, as activists first and lawyers second - the stance Cyril Ramaphosa has reportedly urged lawyers to adopt. ${ }^{29}$

This stance can be an admirable one. South Africa presents us with distinguished examples of lawyers who have indeed become 'activists first' - Nelson Mandela and Abram Fischer among them. But conscientious anti-apartheid lawyers are not, I submit, obliged to see themselves as activists. They might feel, for example, that their professional standing with their peers, on which their effectiveness as lawyers depends, rests on their being, visibly, 'lawyers first and activists second'. Or they might feel that their effectiveness with their clients depends on their retaining the capacity for objectivity that lawyers practise but activists may not prize. Or they might feel that they are better lawyers or better people as lawyers, than they would be if they tried to play an activist role for which they are not well suited. On any of these grounds, and no doubt more, men and women can properly conclude that it is their responsibility to serve as lawyers rather than to become activists themselves.

I have already suggested, however, that no lawyer in South Africa can escape the responsibility for choosing which case, out of the many possible ones, to undertake. A lawyer indifferent to political matters might choose cases based on the fees they brought in, and as a practical matter even a lawyer committed to the struggle against apartheid cannot wholly ignore this criterion. (This reality underlines the importance of the

29 G Davis 'Lawyers Group Calls for "isolation" of Bar Councils' Weekly Mail 27 May 1988 at 8 . I do not mean to suggest that Ramaphosa necessarily intended to support the conception of lawyers' responsibility that $I$ sketched in the text. A call for lawyers to be activists first can be interpreted in a wide variety of ways. 
political and moral criteria applied by those who assist in funding these lawyers.) Where money and other nonpolitical concerns - 'gaining experience', 'handling interesting matters' and the like - are not dispositive, however, I see no way for lawyers to make their decisions except by applying some political or moral standards. It may be quite legitimate for lawyers to borrow those standards, for example by adhering to a principle of 'taking cases identified as important by representative popular organizations'. At the least, however, the lawyer must choose to do the borrowing, and is responsible for this choice.

What if the lawyer did take the 'activist first' course? Lawyers who become activists first may conclude that they must make detailed judgments about their professional lives based on political principle. (Non-activists might reach the same conclusion.) Such lawyers might conclude as a matter of politics that participation in the legal system is a mistake, and that the contrary view of the majority of other victims does not bind them to join in that mistake. Many activists might nonetheless believe that so long as the people with whom they work hold onto the idea of legal representation, it is not the activists' place to deny them access to counsel. Presumably, however, activists who believe that lawyers' work ultimately does more harm than good will at least try to lead the people as a whole to share that view.

But is it a political mistake to participate in the legal system? We have already seen that such participation can somewhat lessen the impact that the state's emergency apparatus will have on its individual victims. But this immediate boon can have political value as well. The harder it is for the state to punish or coerce any given individual, after all, the easier it is for that individual to continue to play a role in the political struggle. The broader these ripple effects become, the more lawyers' work serves not only to safeguard individual South Africans but also to help provide 'space' for the political movements of which these individuals may be a part.

Moreover, the targets of emergency law are by no means limited to individuals. When the state seeks to muzzle free reporting by the press, or to clamp down on the activities of an anti-apartheid organization, any successful challenges to the state's designs obviously may effect the broader course of change. It would be a mistake to overstate the victories that can be won on these fronts, for extensive media controls have been imposed and many anti-apartheid organizations deprived of their legal right to carry on any activities whatsoever. Yet lawyers may have had some successes all the same, for example in limiting the state's efforts to ban alternative newspapers, or in securing some legal room for events such as the Mandela birthday celebrations of 1988 or the beach demonstrations of 1989.

Perhaps an example, not from emergency law but from nearby, will confirm this point. Late in 1988 five men were sentenced to lengthy 
prison terms at the end of the 'Delmas' treason trial. In that case more than 400 days of trial were taken up with an examination of the actions of the individuals actually facing charges in the case and of countless others not before the court - in a sense, the entire society. That only four of the accused ultimately were sentenced to imprisonment is a partial, bittersweet victory for the accused, and for their lawyers. ${ }^{*}$

But a greater victory may also have been won. The massive defence mounted on behalf of the 22 people indicated in this case (and similar efforts in other recent treason cases) may have slowed the march of government repression of the national resistance that sprang up in the mid-1980s, for this work helped to deprive the government not only of convictions but also of the imprimatur for broader oppression which a quick and easy conviction of leading activists for treason could have provided. Denied this weapon for a time, the government found another device in early 1988 in the effective banning of the United Democratic Front under the emergency. ${ }^{30}$ Yet some precious time had perhaps already been won, for it may be that organized opposition to apartheid would have been even more bluntly and thoroughly suppressed had it been easy, rather than difficult, for the state to run its opponents through the gauntlet of a treason trial.

Still, even after generously measuring the individual and political value of emergency law work, we should also ask whether its costs might outweigh its value. In making such an evaluation, lawyers (whether activists or not) might well hesitate to sacrifice relatively tangible benefits to clients and others in light of costs that might be less certain or less immediate. But we could hardly rule out a priori the possibility that some lawyers might find, perhaps correctly, that these costs were too much to pay. ${ }^{31}$

Let us consider two types of potential costs. First, a focus on legal protections might divert activists and potential activists from more fruitful forms of activity. After all, if it is clear that the courts are unlikely to alter the fundamental contours of the state's security system, then perhaps those who oppose that system should look for alternative means of challenging it.

This argument starts from a somewhat mistaken premise, namely that legal work and political work are mutually exclusive alternatives. We have just seen one reason that this premise is misleading - that in fact legal work may sustain and protect political efforts. It is not misleading, however, to recognize that legal work might come to enjoy a reputation for efficacy that it did not deserve. The work of lawyers might as a result

30 GN 334 GG 241115724 February 1988.

31 Whether those who speak for the oppressed, in political fora or in courts, have an obligation not to deprive their people of attainable benefits despite possible long-term costs is an issue beyond the scope of this article. See M Walzer Obligations: Essays on Disobedience, War, and Citizenship (1970) 46-70. 
attain a cachet that exalted its importance above that of the political campaigns it might seek to benefit, or even encouraged people to dispense with political organizing in favour of litigation.

The significance of this possibility can only be measured empirically. An activist lawyer might ask whether there exist other means of aiding political struggle which promise greater success at this time - and might find, regretfully, that under a state of emergency the work of lawyers ranks quite highly in terms of its effectiveness among the courses of action available. An activist might also ask whether those who might undertake more political forms of protest in fact lapse into quiescence because of the availability of courtroom challenges. It may be that such misplaced dependence on the law can develop, and so should be a matter of concern in framing tactics in any particular situation. Lawyers may be able to minimize this danger without departing the field altogether, if they shape their relations with their clients in light of a recognition of this potential. ${ }^{32}$ More broadly, however, the history of the past decade is a history of mass mobilization as well as widespread litigation, and it is simply difficult to see in that history any evidence of a general tendency on the part of South Africa's oppressed majority to forego political challenge for judicial disquisition.

The view that legal work undercuts political work also seems to entail a relatively narrow definition of 'legal work'. Much of what lawyers do is of course in courts or similar professional settings, and thus could pose the risk of impairing mass mobilization discussed above. But not all that lawyers do is so narrowly confined. Consider, for example, the fast undertaken by lawyers for emergency detainees in support of the detained hunger strikers. ${ }^{33}$ It may seem odd to describe this fast as a form of lawyers' work. Even if the fast itself was not part of the practice of emergency law, however, the fact that the fasters were lawyers was part of what made the fast a noteworthy symbolic gesture, and so the lawyers' professional status directly supported this arguably extra-professional conduct.

In any case, less vivid forms of political work have long been recognized as within the sphere of lawyers' professional obligations. Lawyers as a profession, in the bar councils and law societies, can legitimately decry unjust laws and work for their reform. Two South African organizations, Lawyers for Human Rights and the Society for the Abolition of the Death Penalty in South Africa (at least some of whose members are lawyers), have recently pressed the case against South Africa's death penalty. Brian Currin, one of the leaders of this effort, has said that he is "convinced that the lobbying in high places, our execution monitoring programme and the

32 For an insightful description and analysis of the efforts of a lawyer and a community organizer to avoid such unfortunate results see L E White, 'To Learn and Teach: Lessons from Driefontein on Lawyering and Power' 1988 Wisconsin LR 699.

33 See 'Strikers Spark New Spirit in South Africa' 31 Africa News (No 4) 20 February 1989 at 2. 
high profile campaigns have together contributed towards the realization in government circles that something needed to be done' ${ }^{34}$ The risk that lawyers' work will undermine political efforts declines the more their work is understood to include political efforts. (The more laywers undertake political struggle, however, the less they can limit their responsibility for political choice, for as participants in politics they run the risk that one political effort, or strategy, will undercut another.)

A second possible political cost of a focus on legal protections could be the legitimation of the courts, and by extension the government of which the courts are a part. The better lawyers do in their use of the rules of the game - the more useful they are to the individual clients - the more they may, according to this argument, tend to strengthen support for the current regime and to deflate opposition to it. We might take the fact that opponents of oppression in a wide range of countries have attempted to invoke the law as a sword or shield on their behalf as some evidence that those closest to these questions do not usually see the risk of legitimation as a dispositive one. Even if this risk is usually not prohibitively severe, however, it might be so in South Africa. In assessing it, we must remember the various audiences before whom these events are played out. Let us consider three different audiences, beginning with the audience perhaps most easily persuaded of the legitimacy of South African instutitions - South African whites - and then briefly discussing the audience outside South Africa before looking in more detail at the possible impact on the largest audience in South Africa itself - South African blacks.

South Africa's whites, or at least many of them, appear to place real value on their society's adherence to law. The extraordinary elaboration of security and emergency laws, marking out in immense detail the state's sweeping powers, itself reflects this attachment. Praise of the quality of the South African judiciary can bespeak the same feeling. ${ }^{35}$ The roots of this sentiment are complex. They may range from genuine attachment to the idea of the rule of law, to pragmatic recognition of law's efficacy as a tool of social control, to anxious concern for the opinions of other Western nations whose attachment to government by law may be more intense. For such reasons as these, in any event, it may be important to white South Africans' continued support of the government's overall direction that they be able to feel that their society lives by the law. That feeling may be easier to summon up if even the emergency is seen to be grist for lawyers' mill - and easier still if lawyers win an occasional victory.

Thus in this respect lawyers' work may bolster the state. I suspect,

34 G Evans 'Turnabout welcomed as number of hangings declines' Weekly Mail 3 March 1989, at 3.

35 See C J Claassen 'Retain the Bar and Side Bar' (1970) 87 SA LJ 25. ('I am told on good authority that the English judges, who are undoubtedly the most eminent judges in the world, consider only the South African judges as their equals.') 
however, that this almost paradoxical result of lawyers' challenges to state conduct should not be of great concern to the lawyer weighing the political consequences of her work. Most whites are not, unfortunately, profoundly opposed to the present order in South Africa, nor are they the primary engine of political pressure for change. As a result, confirming their support for the current regime probably does not sharply alter the present political equation.

This is not to say that whites' views are irrelevant. If whites' confidence in their own institutions were to decline, that might significantly affect the course of events in South Africa. It is possible that the legitimizing effects of emergency law practice help stave off such a decline. But is it really likely? We may well question whether the existence of emergency law practice (or anti-apartheid practice generally) does greatly affect whites' views on whether their society is ruled by law. To be sure, the visible evidence of this practice - the reports of court cases, the statements by lawyers - receives attention in the press, an attention magnified by the fact that court proceedings can be reported much more freely than many events 'on the street'.

Developments in the courts, however, are only a small part of the political and social scene in South Africa. Troop movements, unrest reports, debates in Parliament, and televised accounts of these events all of these probably form the bulk of the information that South African whites look to in their daily experience of their society. It seems quite possible that if there were no lawyers assisting the victims of apartheid, most whites would still be prone to believe that their society adhered to the law.

Moreover, emergency law work has a distinct defect as a source of legitimation even in the eyes of whites, since such work is by definition focused (on the victims' part) on displaying and condemning the injustices of the existing order. Perhaps even many whites find the reports of such litigation more disturbing than reassuring.

Before considering whether lawyers' work legitimizes the South African government in the eyes of blacks, let us consider briefly its effects on the views of people outside South Africa. It is difficult, of course, to do more than speculate about such effects. Undoubtedly some foreign observers sympathize deeply with South African whites, and might respond to emergency law practice as most of those whites would. I suspect, however, that for most foreign watchers the question is not whether the existing order is a legitimate one, but rather how to encourage it to change. In that case the existence of emergency law practice may well affect their assessment of strategies for bringing about such change - and an activist lawyer in South Africa might worry that outsiders would overestimate the utility of the courts - but their perception of the legitimacy, or rather illegitimacy, of most aspects of the system would not be at issue. If anything, news reports of court action 
might remind outsiders of the state of affairs in South Africa and thus confirm their sense of the illegitimacy of the existing order.

The risk that outsiders may overestimate the utility of legal practice could be a serious concern, but I am inclined to doubt that in fact it currently should be. If the use of the courts and the law is one valuable part of the effort to challenge apartheid, then (given the reality of limitations on the amount of foreign support available at all) it seems unlikely that the result of an overestimation of the value of this strategy will be an absolute 'over-funding' of this effort, in terms of financial or moral support.

It is true that this effort might still be overfunded relative to other deserving candidates for assistance. Even if legal work is receiving a disproportionate share of foreign support, however, a decline in support for this work might not translate into an equivalent increase in assistance to other activities. This could be the case, for example, if those who support the work of lawyers and those who support different strategies, such as union organizing, constitute relatively distinct and non-overlapping groups, whose members do not readily adopt new targets for their aid. Moreover, I doubt that a survey of foreign support for anti-apartheid efforts would actually show anything like a singleminded focus on the activities of lawyers. The possible misdirection of foreign support, in short, does not seem to be an acute concern.

To suggest, finally, that the effect of emergency law practice is to legitimize the system in the eyes of South African blacks is simply implausible. South Africa today is not a state in which the black majority accepts the legitimacy of its white rulers' dominance. It is wholly unlikely that the partial checks on that dominance that emergency litigation can achieve will confer an aura of virtue on the government as a whole. That the police can be stopped does not necessarily mean they should be praised! 36

A narrower version of this argument, however, may be more credible. If people go to court and win some relief, is it not possible that they will conclude that the courts - the Supreme Courts, in particular - deserve more respect than the rest of the current system? Is it not possible that South African blacks might entertain the view that 'justice' is available, at least some of the time, in these courts?

We should not overstate the likelihood that emergency law work will produce this result, given its focus on some of the worst features of the existing order and given its decidedly modest level of success. We should also remember that lawyers' work broadly understood can include political gestures meant to counter the subliminal legitimation that conceivably is the result of even unsuccessful efforts in court. The fasting 
lawyers' declaration that the courts had failed their detainee clients is such a gesture.

A precisely targetted boycott might be another.$^{37}$ Obviously such a step could have costs in terms of whatever chance of legal relief was foregone as a result. But these costs would by no means be as severe as the costs of foregoing all legal remedies indefinitely in a general boycott would be. Moreover, unlike a total boycott - a gesture that would surely have more delegitimizing impact but that seems wholly unlikely at this time narrowly focused refusals to invoke legal procedures might be organizationally feasible. ${ }^{38}$

Let us grant, nonetheless, that it is possible that blacks might conclude as a result of judicial victories that justice can sometimes be won in the courts. Then we might say that emergency law practice can legitimize the courts in the eyes of blacks, to the extent that the courts are seen as providing fair results or, failing that, at least fair process. Whether South African blacks do give the courts a greater measure of legitimacy than they accord to other institutions of the government is not entirely clear, but let us assume for argument that they do. If emergency law practice contributes to this attitude, should we count this effect as a cost of practice?

If South Africa's Supreme Court generally is an institution in which honest judges seek to act fairly, and are prepared on occasion to follow their convictions or the law's dictates even to the extent of opposing, in some measure, the worst excesses of the government, it would seem that these virtues should be recognized by blacks just as by other opponents of apartheid (although they should not be exaggerated). To say that they should not be recognized would be to say that people should remain ignorant of such bright spots as the South African system presents - a view that could be held but that does not reflect great respect for the judgment of those to be kept in ignorance.

There is, in addition, a political reason for holding that it is extremely important that the relative independence of the South African courts be widely seen, and by both blacks and whites. That reason is that the attitude of South Africa's people towards the courts now will influence their attitude towards courts in the future. It was possible for American colonists to hate the British monarchy and yet retain much of British law. It seems equally appropriate for South African citizens to hate the system of apartheid but retain in the future the beneficent principles of the

37 The reported one-month boycott of Israeli military courts by Palestinian lawyers would be an example of such a focused boycott. See 'Palestinian lawyers boycott courts' The Guardian 3 January 1989 at 7 .

38 So long as such a boycott was carried out with the consent of the clients in question, I assume it would violate no rules of South African legal ethics or law. It is not the purpose of this article to urge any unlawful conduct by lawyers - nor, indeed, to do more than recognize the potential availability of the boycott device as an element in lawyers' work. Assuming the tactic is available, its effectiveness would remain to be considered. 
common law that still inhere within the South African legal system, and the welcome tradition of judicial independence that also still holds meaning. It is impossible to predict, of course, what the impact of current judicial decisions or of their public reception will be on the character of South Africa's government after apartheid. Nonetheless it makes sense to expect that the more reality lawyers can give to the highest aspirations of the law now, the stronger the appeal of these ideas will be to the citizens of a future South Africa. In this respect, then, a qualified legitimation of the courts through emergency law work would be, in political terms, a benefit rather than a cost of this enterprise.

To this political benefit we should add another that we have not yet assayed. It is possible that the courts will have a valuable political role to play along the road to a future South Africa as well as when the journey is complete. We cannot know the course by which apartheid may be brought to an end, although it is clear that important forces within (and without) South Africa, both black and white, are pressing for the emergence of a nonracial democracy. The recent freeing of some political prisoners, however, encourages the hope that there will come a time in South Africa when the hand of state racism lifts somewhat, and a space for popular pressure and for reform grows. It may be difficult to recognize that time - as it may have been difficult to know in 1954 that segregation in the United States was ripe for attack. It may also be difficult, even when this space opens up, for those opposed to apartheid to challenge the well-organized, perhaps even violent, forces opposed to change - even more difficult than such efforts were in the most challenging moments of the American civil rights struggle.

When that time comes an independent and sympathetic judiciary may play a role much greater than the role the South African courts have played in years past. The government may find it convenient to place responsibility for some changes largely in the hands of the courts - as the United States in a sense did in the struggle over school desegregation. (The adoption of a Bill of Rights might be one expression of such a strategy.) Moreover, the process of change may have a momentum that encourages courts to go considerably further than the government might desire. The more legitimate the popular struggle for democracy becomes, the more reluctant courts may be to approve the use of law for its suppression. ${ }^{39}$

But to have an independent and sympathetic judiciary for this difficult

39 The willingness of Van der Walt J to 'tak[e] into account the conditions in Alexandra . . . [and] the amount of perceived provocation of the residents in Alexandra because of what they subjectively saw as unwarranted police action' in acquitting Moses Mayekiso and others of sedition exemplifies this potential. $S v$ Mayekiso WLD 5 May 1989 Case No 115/89, unreported, typed judgment at 55 . The duty to hear the other side may already compel judges to hear much more extensive and vivid explanations of blacks' struggles than other whites encounter. The more legitimate this struggle becomes, in addition, the more judges may welcome such evidence even if they are not compelled to do so. 
but welcome future argues for, if indeed it does not require, insisting on such a judiciary now. If lawyers in South Africa do not press for decent decisions, and do not struggle to sustain and expand the positive elements of South African law, that law will grow worse. If liberal judges in South Africa were to resign, there would be, as Mureinik has pointed out, no sympathetic judges available to turn to. ${ }^{40}$ If South African legal scholars abandon a criticism of their courts that asserts that the courts, now, should do better than they do, it may be harder to make the case for positive judicial intervention when that intervention would be most far-reaching. The pressure of emergency litigation is only a part of this insistence on justice, but it is a part. On this score too, therefore, the practice of emergency law may be valuable to the broader political challenge to apartheid.

In sum, political considerations do not call for abandonment of the practice of emergency law despite its benefits to individual clients. Properly handled, lawyer's challenges to the emergency should not undercut political efforts. Their work can help move South Africa forward rather than restore moral force to the system of the past.

\section{ConCLUSION}

By now, however, we are obviously discussing the effects of antiapartheid legal work in general, rather than the unique merits of emergency law practice. Even if lawyers opposed to apartheid can fruitfully express that conviction in their legal practice, it would not automatically follow that they should do so in the particular field of the emergency. ${ }^{41}$ After all, the courts have been less receptive to emergency law claims than they are to the claims that South Africa's oppressed people have brought in a variety of other contexts. While the courts'

40 Mureinik's point is quoted in J Dugard 'Should Judges Resign? . . A Reply to Professor Wacks' (1984) 101 SALJ 286 at 294.

41 Indeed, it would not necessarily follow that anti-apartheid lawyers should devote all or most of their professional lives to lawyering against apartheid. It is no doubt true, in South Africa as in the United States, that lawyers can profoundly assist the cause of human rights in part-time efforts that are in a sense ancillary to a nonpolitical career. Lawyers who practise in seemingly nonpolitical fields such as corporate law may also find opportunities to counsel their powerful clients about those clients' broader political or moral obligations. Even lawyers whose professional careers are wholly apolitical may find ways to express their convictions in other parts of their lives.

In a society tainted only by 'moderate' levels of injustice, consideration for the autonomy of individual human beings who become lawyers may lead to the conclusion that choices not to address injustice through one's practice as a lawyer should be altogether beyond reproach. I think it is fair to say that, in a society so riven by injustice as South Africa's, decisions not to become closely engaged in the effort to correct that injustice are more troublesome than they would be in less anguished lands. Such decisions by lawyers, whose selection of a career entails at least involvement in the world of affairs and arguably some special responsibility for the assurance of justice, seem particularly problematic. 'Close engagement' can certainly be found in work that is by no means full-time - the South African bar offers outstanding examples of such part-time, yet intense, involvement - but at some point on the spectrum a lawyer's separation from the fray does seem to pose a moral question. 
unresponsiveness may also mean that any risk of lending legitimacy to South Africa's institutions is also reduced, it is easy to understand why lawyers might wish to practise in fields where more could be achieved.

If the arguments I have made about emergency law can broadly be generalized to other fields of legal challenge to apartheid, then it would follow that legal efforts on many different fronts are valuable (and so I believe). I can offer no criterion by which to judge the exact balance of emergency law and other forms of work that would be ideal. Even if I thought it possible to argue convincingly that greater emphasis on emergency cases was appropriate, I would not want to suggest that lawyers practising anti-apartheid law ... a group facing difficulties enough as it is ... should discount the sense of satisfaction that other areas of this practice may give them.

I do want to argue, however, that it is important that emergency law work continues even though other fields of law may offer more frequent victories. I doubt that this proposition is a controversial one, but it may be worth brief discussion nonetheless. One reason for maintaining this practice is a moral proposition: such profound breaches of human rights should not be left unopposed. Were lawyers' efforts against them wholly ineffective, the need to express opposition to such injustice would remain. But there is also a much more practical reason. The fact is that the emergency has been the cutting edge of the South African government's effort to control the rise of effective black opposition to apartheid. Even now this edge is still sharp. The direct victims of the emergency are likely to be those individuals and those organizations who are in the forefront of the effort to bring change to South Africa. Protecting the people who have taken up such roles is important morally; preserving space for them and the organizations of which they are a part is important to the course of political events as well. That course is often bleak and hard to predict, but can hardly be abandoned.

South African lawyers are pressing the claims of the oppressed, both those in detention and those suffering only the injustices of normal South African life. Often this work must be deeply frustrating - perhaps even more frustrating than the efforts of the lawyers involved in the first steps of the struggle against racial segregation in the United States, decades before Brown $v$ Board of Education. ${ }^{42}$ But the decades of legal work and popular struggle here did bear fruit. Looking back, we can say that the potential - not the guarantee, but the potential - for that victory was always present in the little-used constitutional mandate of equal treatment for blacks. With this perspective in mind, we can similarly value the intellectual and moral potential still inherent in South African law, and the prizes to be won by pressing, at the bar, on the bench, in the academy, and in the dock, for that potential to be realized. 